\title{
EVALUASI MANAGEMEN NUTRISI BALITA DI POSYANDU CATHELYA DESA DUKUH MENCEK KECAMATAN SUKORAMBI
}

\author{
Susi Wahyuning Asih \\ (Fakultas Ilmu Kesehatan, Universitas Muhammadiyah Jember, email: \\ susiwahyuningasih@ymail.com)
}

\begin{abstract}
ABSTRAK
Nutrisi adalah kebutuhan dasar manusia, termasuk pada balita. Proses tumbuh kembang balita membutuhkan nutrisi yang cukup. Hal ini merupakan kondisi yang sangat kompleks. Diperlukan persiapan yang cukup selama memasuki proses tumbuh kembang sehingga dapat memberikan panduan untuk menjalani masa perkembangan anak balita. Manajemen nutrisi bagi balita ini didasarkan pada konsekuensi proses pertumbuhan dan perkembangan balita. Penelitian bertujuan untuk mengetahui gambaran tentang bagaimana manajemen nutrisi pada masa pertumbuhan Balita. Metode penelitian ini menggunakan desain deskriptif dengan pendekatan cross sectional dengan data retrospektif. Jumlah sampel yang digunakan adalah semua balita di RW 3 Desa Dukuh mencek sukorambi yang ada di posyandu. Hasil penelitian ini akan disajikan dengan analisis tendensi sentral. Hasil penelitian ini menunjukan bahwa evaluasi manajemen nutrisi pada balita berada pada kategori cukup. Peningkatan pengetahuan dan aplikasi pada manajemen nutrisi diposyandu Cathelya harus lebih disosialisasikan lagi.
\end{abstract}

Kata kunci : manajemen, Nutrisi, Ibu, balita

\section{ABSTRACT}

Nutrition is a basic human need, including for toddler. The process of growth and development of toddlers requires adequate nutrition. This is a very complex condition. Adequate preparation is needed during entering the growth and development process so that it can provide guidance for living under five. Nutrition management for toddlers is based on the consequences of the process of growth and development of infants. The research aims to find of how nutrient management for toodlers. This research method used descriptive design with cross sectional approach with retrospective data. The number of samples were all mothers and children under five in RW 3 in Dukuh Mencek Village, sukorambi in posyandu. The results of this study will be presented with a central tendency analysis. The results of this study show that the evaluation of nutrition management is in the moderate category. Increased knowledge and applications on nutrition management at Cathelya's community should be further socialized.

Keywords: management, nutrition, mother, toddler 


\section{LATAR BELAKANG}

Kurangnya nutrisi pada Bayi dan Balita tidak lepas dari peran pemberian ASI. ASI merupakan makanan utama bagi bayi sampai dengan usia 6 bulan. Proses pemberian ASI pada balita disebut menyusui. Menyusui merupakan kodrat setiap wanita yang memiliki anak. Manajemen nutrisi adalah tata laksana yang diperlukan untuk menunjang keberhasilan menyusui. Dalam pelaksanaannya terutama dimulai pada masa kehamilan segera setelah persalinan dan pada masa menyusui selanjutnya (Direktorat Gizi Masyarakat, 2005). Kondisi ini sesuai dengan WHO (2011), janin yang kekurangan nutrisi akan mengalami hambatan pertumbuhan intra uterine dan akan beresiko setelah lahir dapat terjadinya retardasi pertumbuhan awal, Di Desa Dukuh Mencek terutama diposyandu Cathelya banyak sekali Balita yang menggunakan susu formula dengan alasan ASI tidak keluar. Kondisi inilah yang mengakibatkan cakupan ASI ekslusifnya menjadi rendah..

Ruang lingkup manajemen nutrisi periode balita meliputi ASI Eksklusif, teknik pengolahan makanan, jenis makanan, jumlah makanan, memberikan ASI dan pemenuhan gizi selama ibu periode menyusui. Ruang lingkup manajemen nutrisi periode pasca melahirkan meliputi ASI Eksklusif, teknik memberikan ASI dan pemenuhan gizi selama ibu periode menyusui. Pada balita proses ini kadang kadang terlupakan sehingga mengakibatkan produksi ASI tidak maksimal sehingga berakibat pada penununan cakupan ASI ekslusif. Berdasarkan kondisi diatas maka peneliti tertarik untuk melakukan penelitian manajemen nutrisi pada balita di posyandu cathelya dukuh mencek, kecamatan sukorambi.

\section{METODE PENELITIAN}

Penelitian ini merupakan jenis penelitian survei yang bersifat deskriptif ekploratif dengan pendekatan cross sectional study. Penelitian dilakukan di Posyandu Cathelya Desa Dukuh Mencek Kecamatan Sukorambi. Variabel penelitian ini adalah managemen nutrisi pada balita di posyandu Cathelya. Populasi penelitian adalah seluruh balita dan ibu yang ada di posyandu Cathelya sebanyak 30 responden. Seluruh populasi digunakan sebagai sampel penelitian (total sampling). Pengumpulan data karakteristik responden dilakukan melalui pengisian kuesioner penelitian. Data evaluasi manajemen nutrisi selama pertumbuhan, perkembangan balita juga dikumpulkan melalui pengisian kuesioner. Data yang diperoleh dilakukan analisis statistik deskriptif (Mean, Median, Standart Deviasi).

\section{HASIL}

Data karakteristik responden sampai dengan evaluasi managemen Nutrisi Balita Di Posyandu Cathelya Desa Dukuh Mencek Kecamatan Sukorambi. 
Tabel 1 Karakteritik responden pada ibu di posyandu Cathelya Juli 2015

\begin{tabular}{cccc}
\hline Variabel & Kategori & Jumlah & $\%$ \\
\hline Usia & $15-20$ Tahun & 12 & 44 \\
\cline { 2 - 4 } & $21-25$ Tahun & 15 & 66 \\
\hline Pendidikan & SMA & 15 & 55 \\
\cline { 2 - 4 } & SMP & 8 & 29 \\
\cline { 2 - 4 } & SD & 2 & 16 \\
\hline Pekerjaan & IRT & 27 & 100 \\
\hline
\end{tabular}

Berdasarkan tabel 1 diatas terlihat bahwa sebagian besar responden berada pada usia 20 sampai 25 tahun yaitu 15 orang
(15\%), sebagian besar berpendidikan SMA yaitu 15 orang (55\%) dan totalitas ibu rumah tangga yaitu 27 $(100 \%)$

Tabel 2 Evaluasi manajemen nutrisi pada masa pertumbuhan pada balita diposyandu Cathelya Juli 2015

\begin{tabular}{|c|c|c|c|}
\hline & Kategori & Jumlah & $\%$ \\
\hline \multirow{3}{*}{$\begin{array}{l}\text { Manajemen } \\
\text { Nutrisi } \\
\text { balita }\end{array}$} & Baik & 10 & 37 \\
\hline & Cukup & 15 & 55 \\
\hline & Kurang & 2 & 8 \\
\hline
\end{tabular}

Berdasarkan tabel 2 diatas dapat memiliki kategori cukup dalam dilihat sebagian besar responden manajemen nutrisi balita

Tabel 3 Evaluasi manajemen nutrisi pada masa pertumbuhan balita di posyandu Cathelya Juli 2015

\begin{tabular}{llll}
\hline Variabel & Kategori & Jumlah & $\%$ \\
\hline Manajemen & Baik & 6 & 22 \\
\cline { 2 - 4 } $\begin{array}{l}\text { nutrisi balita pada } \\
\text { masa } \\
\text { pertumbuhan }\end{array}$ & Cukup & 17 & 63 \\
\cline { 2 - 4 } & Kurang & 4 & 15 \\
\hline
\end{tabular}

Berdasarkan tabel 3 diatas terlihat bahwa sebagian besar responden memiliki kategori cukup dalam manajemen nutrisi selama pertumbuhan.

\section{PEMBAHASAN}

Manajemen nutrisi merupakan suatu proses yang berkelanjutan mulai dari kehamilan sampai dengan masa menyusui. Berdasrkan penelitan ii diperoleh hasih sebgian besar responden berada pada usia reproduksoi sehat yaitu usia $20-25$ tahun. Sehingga sangat dimungkinkan untuk melakukan prosess manajemen nutrisi secara optimal. Budiono (1998) menyatakan bahwa perubahan perilaku disebabkan karena proses pendewasaan (maturation). Melalui perjalanan umurnya semakin dewasa umur individu yang bersangkutan akan melakukan adaptasi sikap dan 
perilaku hidupnya terhadap lingkungan.

Dengan pemahaman kondisi diharapak mampu melaksanakan proses manajemen nutrisi.Tingakt pendidikan responden sebagian besar mengenyam pendidikan terakhir SMA yang merupan pendidikan dasar wajib pemerintah. Secara kategorikal tingkat pendidibikan bisa digolonkan pada kategori pendidikan sedang. Menurut Budiono (1998) tingkat pendidikan individu yang merupakan faktor penting yang mempengaruhi sikap dan perilaku untuk hidup sehat. Solita (1993) bahwa pendidikan bukanlah satu satunya carauntuk mengubah sikap dan perilaku individu maupun kelompok. Menurut Dewi (2008) bahwa pendidikan merupakan penuntun manusia untuk berbuat dan mengisi kehidupan yang dapat meningkatkan kualitas hidup.Kondisi diatas mempengaruhi perilaku dalam pelaksanaan manajemen nutrisi pada kategori cukup baik pada fase kehamin maupun pada masa menyusui.

Perubahan perilaku seseorang sayang juga bergantung padahal lain yaitu informasi dar luar yang memberikan pengaruh terhada pemikiran yang ada pada dalam diri responnden hal ini sejanal dengan Azwar (2007) menyatakan bahwa sumber informasi dalam memberikan pesan pesan yang berisi sugesti yang dapat mengarahkan opini seseorang. Adanya informasi baru mengenai sesuatu hal memberikan landasan kognitif baru bagi terbentuknya sikap terhadap hal tersebut. Pesan pesan sugestif yang dibawa oleh informasi tersebut, apabila cukup kuat akan memberikan dasar afektif dalam menilai sesuatu hal sehingga terbentuklaharah sikap tertentu pula.

\section{SIMPULAN}

Berdasarkan hasil dan pembahasan yang telah dipaparkan maka dapat disimpulkan bahwa:

1. Karakteristik respondenbahwa sebagian besar responden berada pada usia 20 sampai 25 tahun yaitu 15 orang $(15 \%)$, sebagian besar berpendidikan SMA yaitu 15 orang $(55 \%)$ dan totalitas ibu rumah tangga yaitu 27 (100\%).

2. Sebagian besar responden memiliki kategori cukup dalam manajemen nutrisi selama kehamilan

3. Sebagian besar responden memiliki kategori cukup dalam manajemen nutrisi selama menyusui

\section{SARAN}

1. Bagi petugas kesehatan

Dalam pelaksanaan penyuluhan senstiasi ditingkatkan tidak hanya pada ANC tetapi evaluasi pelaksaan pada saat menyusui harus leih ditingkatkan lagi. Upaya ini bertujuan untuk meningkatkan cakupan ASI ekslusif.

2. Bagi masyarakat

Dalam aplikasi dilapangan proses pendampingan dan dukungan bagi ibu hamil dan menyusui harus terus dipertahankan dan ditingkatkan. Pembentukan KP ASI dimasyarakat menujang keberhasilan program ASI ekslusif.

3. Bagi pemegang kebijakan program

Lebih pro-aktif pada upaya tindak lanjut terhadap laporan cakupan ASI ekslusif 


\section{DAFTAR PUSTAKA}

Adriani, M \& B. Wirjatmadi. (2014). Gizi dan Kesehatan Balita (Peranan Mikrozinc pada Pertumbuhan Balita). Jakarta: Kencana Prenadamedia

Almatsier S, Soetardjo S, \& Soekatri M. (2011). Gizi Seimbang dalam Daur Kehidupan. Gramedia Pustaka Utama, Jakarta

Angka Kecukupan Gizi (AKG). (2014). Angka Kecukupan Gizi yang dianjurkan bagi bangsa Indonesia. Dirjen Bina Gizi dan Kesehatan Ibu dan Anak. Kemenkes RI.
Departemen Kesehatan RI. (2000). Gizi Seimbang menuju Hidup Sehat bagi Balita. Jakarta: Depkes RI.

Group.Direktorat Gizi Masyarakat (2005). Manajemen Nutrisi Kepmenkes RI No. 450/Menkes/SK/IV/2004 tentang pemberian ASI secara Eksklusif pada bayi di Indonesia.

Roesli, U. (2006). Mengenal ASI Eksklusif. Jakarta : Trubus Agrudaya.

Prasetyono, D., 2009. Buku Pintar ASI Eksklusif. Cetakan pertama. Jogjakarta: Diva Press (Anggota IKAPI). 